\title{
Scientific Drilling in a Central Italian Volcanic District
}

\author{
by M. Teresa Mariucci, Simona Pierdominici, and Paola Montone
}

doi:10.2204/iodp.sd.5.04.2007

\section{Introduction and Goals}

The Colli Albani Volcanic District, located $15 \mathrm{~km} \mathrm{SE}$ of Rome (Fig. 1), is part of the Roman Magmatic Province, a belt of potassic to ultra-potassic volcanic districts that developed along the Tyrrhenian Sea margin since Middle Pleistocene time (Conticelli and Peccerillo, 1992; Marra et al., 2004; Giordano et al., 2006 and references therein). Eruption centers are aligned along NW-SE oriented major extensional structures guiding the dislocation of MesoCenozoic siliceous-carbonate sedimentary successions at the rear of the Apennine belt. Volcanic districts developed in structural sectors with most favorable conditions for magma uprise. In particular, the Colli Albani volcanism is located in a N-S shear zone where it intersects the extensional NW- and NE-trending fault systems. In the last decade, geochronological measurements allowed for reconstructions of the eruptive history and led to the classification as "dormant" volcano. The volcanic history may be roughly subdivided into three main phases marked by different eruptive mechanisms and magma volumes. The early Tuscolano-Artemisio Phase (ca. 561-351 ky), the most explosive and voluminous one, is

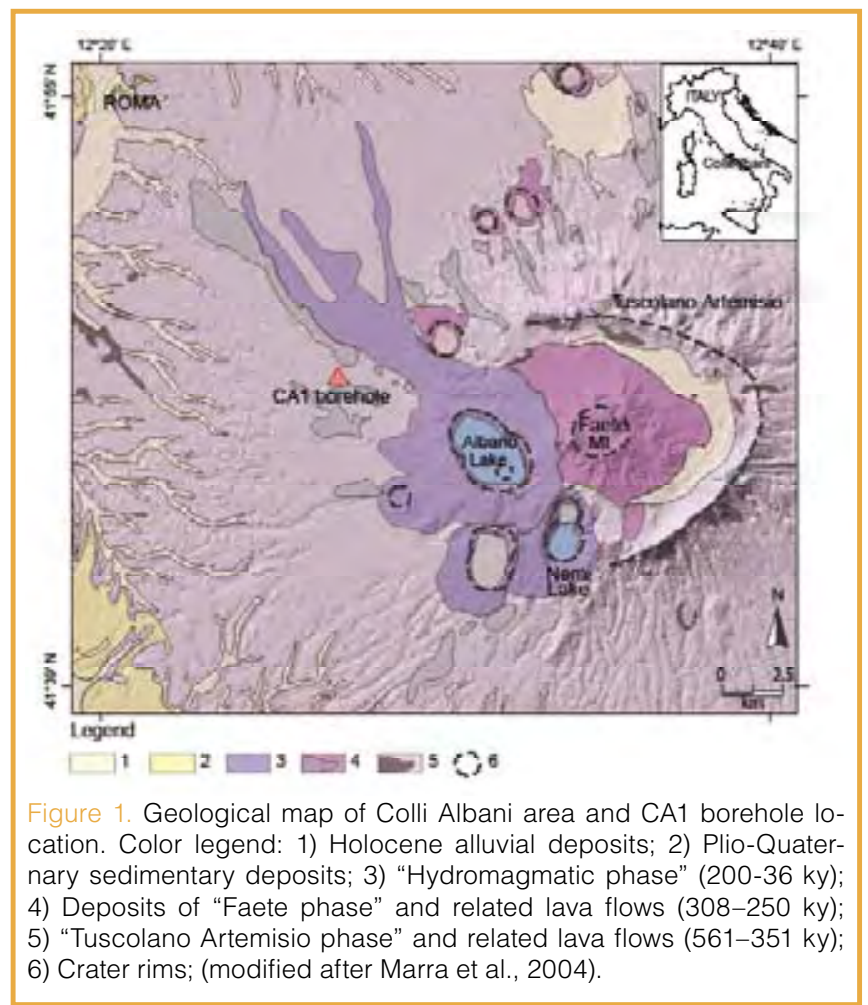

characterized by five large pyroclastic flow-forming eruptions. After a 40-ky-long dormancy, a lesser energetic phase of activity took place (Faete Phase; ca. 308-250 ky), which started with peripheral effusive eruptions coupled with subordinate hydromagmatic activity. A new 50-ky-long dormancy preceded the start of the late hydromagmatic phase (ca. 200-36 ky), which was dominated by pyroclastic-surge eruptions, with formation of several monogenetic or multiple maars and/or tuff rings.

Periodic unrest episodes have been directly observed in the area of most recent volcanism, posing a threat not only to this densely populated area but also to the nearby city of Rome (Amato and Chiarabba, 1995; Chiarabba et al., 1997; Pizzino et al., 2002). Unrest activities include i) intermittent seismic swarms of shallow depth and small-moderate magnitude earthquakes, ii) episodes of $\mathrm{CO}_{2}$, radon, and $\mathrm{H}_{2} \mathrm{~S}$ emissions, and iii) pulses of surface uplift. In the framework of two multidisciplinary projects (DPC and FIRB, see details below), the Colli Albani 1 borehole (CA1, $350 \mathrm{~m}$ ) was drilled to directly investigate the volcano at depth (Mariucci et al., 2007).

In this project, detailed analyses of borehole data will be coupled to geological, geophysical, and geochemical studies. The main goals are to better characterize the shallow crust structure beneath the volcanic complex, to define the present-day stress field, and to understand the formation and emanation of hazardous gases. Finally, a seismometer will be installed at depth in order to acquire outstanding seismological records without anthropogenic noise.

\section{Drilling and On-site Measurements}

The borehole is on public land about $10 \mathrm{~km}$ south of Rome close to Santa Maria delle Mole village, adjacent to the west rim of the Tuscolano-Artemisio caldera. Considering the high gas concentrations in the aquifers (mainly $\mathrm{CO}_{2}$ and $\mathrm{H}_{2} \mathrm{~S}$ ), which have caused illness and casualties among habitants and animals, a blowout preventer was installed at the wellhead. Moreover, for safety reasons $\mathrm{H}_{2} \mathrm{~S}$ concentrations and combustible gases were constantly monitored.

Drilling was conducted in one stage during April and May 2006 by an Italian company (SO.RI.GE. srl) using a Casagrande $\mathrm{C} 8$ machine and wire-line technique. A vertical borehole and continuous coring down to $350 \mathrm{~m}$ were planned 
to sample volcanic and sedimentary sequences. Wireline coring allowed for a very good core recovery (about 99\%) that enabled reconstruction of the detailed stratigraphy of the volcanic units down to the Plio-Pleistocene sedimentary basement. From top to bottom the borehole stratigraphy consists of the typical volcanic succession pertaining to the TuscolanoArtemisio Phase of activity, spanning the interval

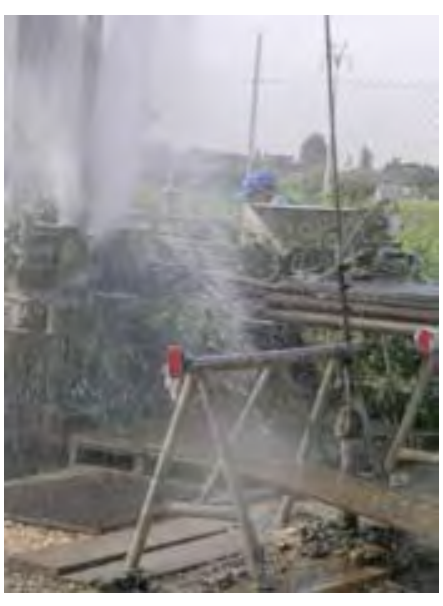

Blowout event. 561-351 ky and a Plio-Pleistocene sedimentary sequence characterized by $\sim 150$ meters of consolidated clays underlying a $~ 20$-m-thick sand layer followed by sand at the hole bottom (the last $\sim 5 \mathrm{~m}$ ).

The borehole was drilled with standard rotary technique down to $25.5 \mathrm{~m}$, followed by wire-line diamond coring with downscaling diameters ( $178 \mathrm{~mm}$ for the first $18 \mathrm{~m}, 152 \mathrm{~mm}$ up to $25.5 \mathrm{~m}, 122.7 \mathrm{~mm}$ up to $204 \mathrm{~m}$, all with $85 \mathrm{~mm}$ core;
$96.1 \mathrm{~mm}$ from $204 \mathrm{~m}$ to $300 \mathrm{~m}$, with $63.5 \mathrm{~mm}$ cores and $75.6 \mathrm{~mm}$ up to $350 \mathrm{~m}$, with cores of $47.6 \mathrm{~mm}$ ). Each 3-m-long core section was cut in pieces of $1-\mathrm{m}$ length and packed in wooden boxes, now curated at Istituto Nazionale di Geofisica e Vulcanologia (INGV)-Rome. Some quick geotechnical analyses were performed on site, such as the Schmidt Hammer and the Barton Comb, to compute the joint compressive strength (JCS) and the joint roughness coefficient (JRC), respectively. A quick analysis of fractures and faults was also performed on the cores in the field.

Three hydraulic fracturing tests had been planned between $320 \mathrm{~m}$ and $350 \mathrm{~m}$ for a first evaluation of the local stress field in the area, in particular to better constrain the minimum horizontal stress. Unfortunately, a blow-out occurred (Fig. 2) during the positioning of the hydraulic fracturing probe in the well, causing a collapse of the deepest part of the borehole. Overpressured fluids (mainly in the form of gases) leaked out of the well for about one hour with a wellhead pressure of $\sim 30$ bar, sputtering up to about $5 \mathrm{~m}$ above ground level for one day with pressure stabilizing around 15 bar. This phenomenon, probably caused by the presence of a sandy unit at 345-350 m, allowed collecting fluid samples for quick geochemical analyses on-site and in the laboratory. Fluids are an aqueous mixture of $\mathrm{CO}_{2}, \mathrm{H}_{2} \mathrm{~S}$,

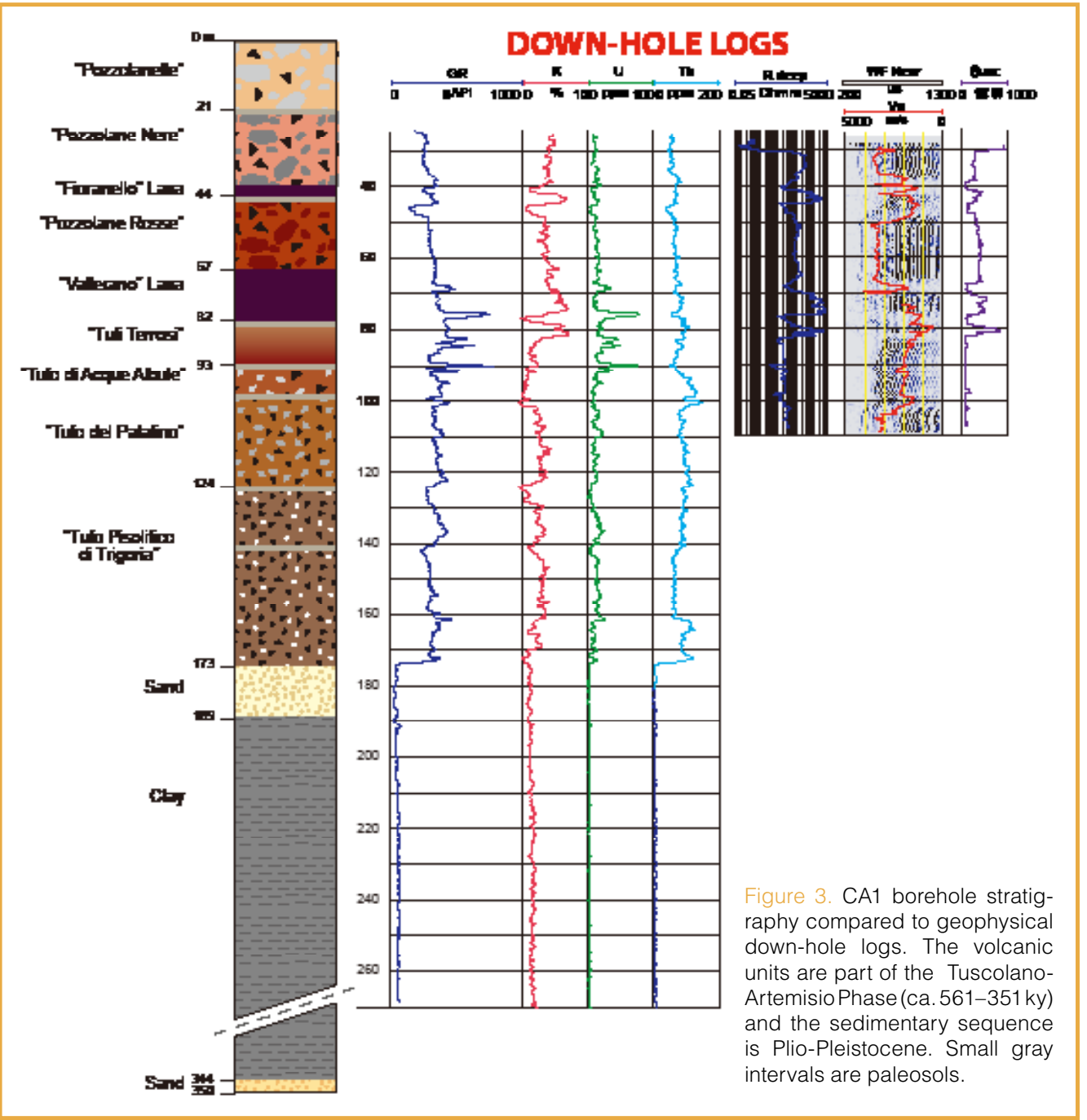

helium, aromatic hydrocarbons, and other gases. Although hampering some geophysical investigations, this blow-out gave direct access to the deepest fluids ever sampled in the area up to now. After fluid samples were collected, the flux was stopped by pumping water into the borehole and restoring the initial conditions.

In order to evaluate the in situ physical properties of volcanic rocks and to estimate the state of stress, the following geophysical $\log$ s were performed using the International Continental Scientific Drilling Program (ICDP) - Operational Support Group (OSG) slim-hole probes: spectrum gamma ray, sonic, magnetic susceptibility, electric resistivity (duallaterolog), four-arm dipmeter, and borehole televiewer. Spectral gamma logs were recorded down to $270 \mathrm{~m}$, whereas other tools were only 
deployed down to $110 \mathrm{~m}$ as a consequence of the blow-out (Fig. 3).

The borehole was cased down to $200 \mathrm{~m}$ and plugged with cement in the lower part hosting a broad-band seismometer. Now it serves as a seismic station for the Italian national centralized seismic network managed by INGV.

\section{Ongoing Research}

Some data analyses and laboratory measurements on samples are still ongoing. We analyzed downhole logs and compared them to the detailed stratigraphy obtained from cores, defining the main physical characters of the main volcanic units. Moreover, selected samples were taken on the most representative volcanic units to determine physical properties such as elastic wave velocities under different pressure conditions. Breakout analyses from both caliper and televiewer data are performed to get the horizontal minimum stress direction and to analyze fractures from televiewer images. All cores from the logged interval were scanned using an optical DMT Core Scanner at GeoForschungsZentrum in Potsdam (Germany) for digital documentation and structural analysis. A lot of fault planes with striae along the sedimentary cores were recognized, and these will be analyzed using an innovative high resolution thermal field emission scanning electron microscope to highlight some characteristics of the microstructures. Ar-Ar dating will be applied to define the age of a drilled lava flow that is poorly known so far, and mineralogical and geochemical analyses will unravel the characteristics of the volcanic units. Biostratigraphic analysis of nannoplankton and foraminifera and detailed measurements of magnetic susceptibility of Pliocene clays will allow us to define the depositional environment and former positions of shorelines. Dynamic tests on the clays will provide data useful to define the local seismic response of the consolidated clays that form the basement of the volcanic sequence below the City of Rome. Measurements of natural gamma radiation on the cores will be compared with downhole measurements. The goal is to integrate core data with new geodetic and seismological data for physical and numerical modeling to understand the behavior of the whole volcanic complex.

\section{Acknowledgements}

This drilling project was funded by the Italian Department of Civil Protection (Project INGV-DPC V3.1 “Colli Albani”), the Italian Ministry of University and Research (Project FIRB "Research and Development of New Technologies for Protection and Defense of Territory from Natural Risks", W.P. C3 "Crustal Imaging in Italy"), and INGV Departments "National Earthquake Center" and "Seismology and Tectonophysics”, Rome, Italy. We thank the ICDP Operational Support Group (GFZ Potsdam, Germany), in particular J. Kück, C. Carnein, and R. Conze.

\section{Research Unit 9 of Project INGV-DPC V3.1}

M.T. Mariucci, F. Marra, P. Montone, S. Pierdominici, F. Florindo (Instituto Nazionale di Geofisica e Vulcanologia, Rome, Italy).

\section{References}

Amato, A., and Chiarabba, C., 1995. Recent uplift of the Alban Hills volcano (Italy): evidence for magmatic inflation? Geophys. Res. Lett., 22(15):1985-1988, doi:10.1029/95GL01803.

Chiarabba, C., Amato, A., and Delaney, P.T., 1997. Crustal structure, evolution, and volcanic unrest of the Alban Hills, Central Italy. Bull. Volcanol., 59(3):161-170, doi:10.1007/ s004450050183.

Conticelli, S., and Peccerillo, A., 1992. Petrology and geochemistry of potassic and ultrapotassic volcanism in central Italy - petrogenesis and inferences on the evolution of the mantle source. Lithos, 28(3/6):221-240.

Giordano, G., De Benedetti, A.A., Diana, A., Diano, G., Gaudioso, F., Marasco, F., Miceli, M., Mollo, S., Cas, R.A.F., and Funiciello, R., 2006. The Colli Albani mafic caldera (Roma, Italy): Stratigraphy, structure and petrology. J. Volcanol. Geotherm. Res., 155:49-80, doi:10.1016/j.jvolgeores.2006.02.009.

Mariucci, M.T., Pierdominici, S., Florindo, F., Marra, F., and Montone, P., 2007. How a borehole can help volcanology: the scientific drilling in the Colli Albani volcanic area (Italy). Workshop on "Volcano Tectonics", Second Cuban Earth Sciences Convention, Havana, Cuba, 20-23 March 2007, Abstract. Poster available on http://www.earth-prints.org.

Marra, F., Taddeucci, J., Freda, C., Marzocchi, W., and Scarlato, P., 2004. Recurrence of volcanic activity along the Roman Comagmatic Province (Tyrrhenian margin of Italy) and its tectonic significance. Tectonics, 23:TC4013, doi:10.1029/ 2003TC001600.

Pizzino, L., Galli, G., Mancini, C., Quattrocchi, F., and Scarlato, P., 2002. Natural gas hazard $\left(\mathrm{CO}_{2},{ }^{222} \mathrm{Rn}\right)$ within a quiescent volcanic region and its relations with tectonics: the case of the Ciampino-Marino area, Alban Hills volcano, Italy. Natural Hazards, 27:257-287.

\section{Authors}

M. Teresa Mariucci, Simona Pierdominici, Paola Montone, Istituto Nazionale di Geofisica e Vulcanologia sezione di Sismologia e Tettonofisica, Via di Vigna Murata 605, 00143, Rome, Italy, e-mail: mariucci@ingv.it.

\section{Photo Credits}

Fig. 2: Photo by S. Pierdominici (INGV)

\section{Related Web Link}

http://hdl.handle.net/2122/2063 